\title{
Iceland's involvement in the anti-apartheid struggle
}

\author{
Jónína Einarsdóttir, Professor, Faculty of Social and Human Sciences, \\ University of Iceland
}

\begin{abstract}
The transnational anti-apartheid movement was heavily motivated by the postwar emphasis on human rights and decolonisation, and challenged by Cold War politics and economic interests. The aim of this article is to examine Iceland's involvement in the anti-apartheid struggles with focus on the establishment of the unified anti-apartheid movement SAGA (Suður-Afríkusamtökin gegn apartheid), its organisation and activities. What were the motives of SAGA's activists and their subjective experiences? The political background in Iceland is outlined as well as a historical overview of anti-apartheid activities including Iceland's voting on resolutions against apartheid at UN and adoptions of sanctions against the South African regime. Iceland's involvement in the antiapartheid struggle was contradictory. During two periods Iceland voted for more radical UN resolutions than did other Western countries, including the Nordic ones. Yet, Iceland adopted sanctions against the South African regime later than the neighbours and the same applies to the establishment of a unified anti-apartheid movement. The branding of the African National Congress (ANC) as communists allowed many to ignore the human right breaches of the South African regime. Most of the activists belonged to left-wing groups or the labour movement, and the relative absence of religious organisations and the Students' Council of the University of Iceland is notable. Embedded in the transnational anti-apartheid network with particular ways of organisation and mobilisation, the activists became emotionally engaged and worked for a moral cause.
\end{abstract}

Keywords: apartheid; Iceland; activists; sanctions; United Nations.

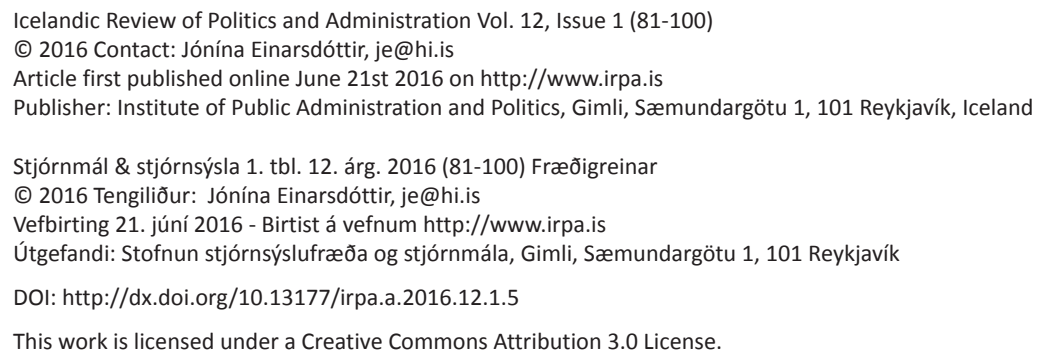




\section{STJÓRNSÝSLA}

\section{Introduction}

During the past decades, the study of social movements has thrived in terms of quantity, scope of inquiry and transformations in theoretical approaches. Until the 1970s, sociology took the lead with its somewhat authoritative perspective centring around the relationship between social structure and political behaviour, and " $[\mathrm{t}]$ he core intellectual puzzles were why political movements were reformist or revolutionary, secular or religious, pragmatic or ideological, nationalist or communist, peaceful or violent" (Walder 2009, 394). This perspective faded out with the entrance of the 'classical agenda' of the 1980s and 1990s that agenda included themes such as "collective action frames, mobilizing structures, and political opportunities” (Roggeband \& Klandermans 2010, 8). These, in turn, have largely been substituted by concepts such as culture, emotions, meaning construction, identity, globalization, networking, resources and policy (Goodwin \& Jasper 2006; Jasper 2011; Roggeband \& Klandermans 2010; Walder 2009).

With sociology still at the forefront, the study of social movements has become increasingly diverse and fragmented within various disciplinary approaches (Roggeband \& Klandermans 2010). While being mostly ignored by cultural sociology, history and social psychology, globalization has become a crucial concept in the study of social movements within structural sociology, anthropology and the political sciences. In that context, focus on new transnational connections and increased access to information has been of paramount interest. At the same time, social movement studies are gradually recognising again the relevance of social structure (Walder 2009). Also, influenced by social phenomenology and symbolic interactionism greater attention is given to individual activists, their agency, engagement, disengagement, and subjective experiences, and studies that focus on the construction of meaning and the role of emotions in social movements have flourished (Jasper 2011). However, these have been criticised for their dismissal of politics or for treating political ideology as a by-product of mobilisation.

With Nelson Mandela's release from jail on 11 February 1990, the transnational anti-apartheid movement, constituted by locally based movements with a variety of origins in their respective societies, achieved one of its central goals (Thörn 2006a). The Boycott Movement in Britain established in 1959 was the first umbrella, anti-apartheid movement outside South Africa, joining South African exiles, trade unions, anticolonial movements and factions from political parties and churches (Gurney 2000). With time, such movements appeared all around the world, and became interlinked in a transnational network when "a transnational political culture emerged through the increasing internationalization of old movements, such as churches and the labour movement, as well as the emergence of new social movements, which addressed global issues" (Thörn 2006b, 293). Despite their diversity, the movements had a common organisational character and particular forms of actions, mobilisation techniques, use of media and mobility (Thörn 2006a, 2006b, 2007, 2009).

Sanctions of South African consumer goods, a strategy first adopted by the South African Congress, became their common goal. As Thörn $(2006,294)$ points out the antiapartheid struggle was not easy and "especially to support the call for sanctions made by 
the ANC." However, in the mid-1980s there was a rapid increase in the number of countries and organisations that adopted some form of economic sanctions against South Africa, including the Nordic Council, the Commonwealth of Nations (UK excluded), the European Community and the US (Evenett 2002). These sanctions were the result of decades of demonstrations and lobbying by anti-apartheid movements in over 100 countries, some of which have already been the focus of research (Thörn 2010).

The Nordic countries took an active part in the global anti-apartheid struggle. In 1994, Sellström initiated the research project National Liberation of Southern Africa: The Role of the Nordic Countries at the Nordic Africa Institute (NAI) in Uppsala. The project resulted in five volumes on the anti-apartheid movements in the Nordic countries, however not including Iceland (Sellström 1999, 2002; Morgenstierne 2003; Eriksen 2000; Soiri \& Peltola 1999). According to Sellström (2002, 7), Iceland was excluded "[d]ue to its marginal involvement in the liberation process in Southern Africa." Concerned with anti-apartheid struggles including official assistance from the Nordic countries to the liberation movements in Southern Africa, Sellström (1999, 20), points out that "Iceland, finally, did not grant the movements any official assistance." In 2003, the NAI initiated The Nordic Documentation on the Liberation Struggle in Southern Africa Project. The project produced a webpage and a database for documentation on the anti-apartheid struggles in Southern Africa supported by the Nordic countries during the period of 1960-1990. Iceland was not included until 2008-2009, when Proscovia Svärd visited Iceland to collect data for the project. She undertook interviews with former activists on their participation in the anti-apartheid movement (Svärd 2010), and published the interviews on the project's website (Nordic Africa Institute n.d.). Further, a seminar was organised in Reykjavík in which the activists recalled their actions against apartheid in Iceland (Einarsdóttir 2009).

This article examines Iceland's involvement in the anti-apartheid struggles. The focus is on the establishment of the unified anti-apartheid movement SAGA (SuðurAfríkusamtökin gegn apartheid), its organization and activities. The article explores the background and commitment of the activists. Who were they? How did they organize themselves and in what activities they engaged. What were their subjective experiences? The article is based on the above-mentioned interviews with Icelandic anti-apartheid activists, seminars, newspapers and magazines filed in timarit.is (Timarit. is 2014), discussions in the Icelandic Parliament, and other relevant publications and documentation. ${ }^{1}$

While being concerned with mobilisation, networking and emotional engagement of volunteers (Jasper 2011; Roggeband \& Klandermans 2010), the article takes notice of the political sociological approach to the study of social movements with attention paid to national polity, political orientation, and the social structure, here conceived "as an empirical description of a historically situated setting" that changes over time (Walder 2009, 400). Further, as argued by Thörn (2006b, 289), "national policies, national organizations, as well as national political cultures played a significant role in shaping the anti-apartheid struggle in different parts of the world." Thus, the article 
begins with a description of the Icelandic political setting. Then attention is devoted to a historical account of anti-apartheid engagement within Iceland, the country's voting on apartheid resolutions in the UN, the cooperation of the Nordic countries, the adoption of sanctions by Parliament and the establishment of a unified anti-apartheid movement, Suður-Afríkusamtökin gegn apartheid (SAGA). Thereafter follows a description on the activists, their actions, motives and subjective experiences. Finally, the findings are discussed and summarised.

\section{Iceland: foreign policy and political culture}

The independence of Iceland from Denmark's colonial rule in 1944 was a result of a century-long struggle that was mostly based on legal arguments. In the postindependence period, four political parties have been the key players in Icelandic politics (Indridason 2005). The right wing, pro-Western Independence Party (IP) has been the most powerful party, and during most of this period it has been the leading party in coalition governments. The Progressive Party (PP), aligned in the centre, has entered various coalition governments to the right with the IP, or left with the Social Democratic Party (SDP), which also frequently collaborated with the IP. The United Socialist Party (USP), and later the People's Alliance (PA), exceptionally entered coalition governments, but played a crucial role due to its strong ties with the trade unions.

Since independence Iceland's foreign policy has rested on membership in international and regional organisations, however bilateral agreements have been favoured (Thorhallsson 2013). Safeguarding markets for marine products, extension of the fishing zone and securing defence arrangements have been the priorities. In 1949, Iceland became a founding member of the North Atlantic Treaty Organization (NATO) and in 1951 an agreement was made with the US on a military base in Keflavík. Simultaneously, Iceland managed to negotiate more Marshall Assistance per capita than any other European country (Gunnarsson 1996). However, the defence arrangements "were extremely controversial and overshadowed other political issues in the country during the Cold War" (Thorhallsson 2013, 11). During the Cod War with the British in the 1970s, the defence agreement with the US became a central issue, and the US military base in Keflavík was secured in late 1970 with the recognition of the 200-mile fishery limit (Ingimundarson 2003).

The Icelandic political culture differs to that of the other Nordic countries. First, the Scandinavian SDPs have been the leading parties, and crucial for the creation of welfare states in Norway, Denmark and Sweden. In contrast, "the [Icelandic] Social Democrats' pro-Western and pro-US stance in foreign affairs brought it closer to the Independence Party ... their social-partnership and pro-welfare ideas had limited influence on public policy" (Jónsson 2014, 518). Second, in contrast to frequent minority governments in the other Nordic countries, most governments in Iceland have been centre-right coalition governments with a clear majority (Jónsson 2014; Thorhallsson 2013). Jónsson $(2014,520)$ argues that such majority governments "are not interested in compromise or consultation with the opposition parties in search of wider support" 
which has resulted in 'polarized" and 'adversarial' political debates in the Icelandic Parliament. Likewise, Thorhallsson argues that in Iceland, "consensual decision-making based on the corporatist model has not developed as it has in the other Nordic states" (Thorhallsson 2013, 8). The third difference and a result of the reported lack of a 'culture of consensus' is the high frequency of strikes in Iceland compared with other countries of the Organisation for Economic Co-operation and Development (OECD) and it is in "vivid contrast to the other Nordic states which are known for low levels of industrial disputes" (Thorhallsson 2013, 8). Likewise, Jónsson $(2014,514)$ refers to the "adversarial political culture in style and practice as manifested in legislative work and public political debate.” According to Jónsson $(2014,518)$, “[t] he unions were mostly controlled by the parties on the Left and the deep political rift between the right-ofcentre governments and the left-wing unions bred distrust and even outright hostilities."

\section{The struggle against apartheid}

Apartheid was "on the agenda of the United Nations (UN) General Assembly from its very first session in 1946" (Reddy 2008, 41). It was first addressed in response to India's complaints over the racial discrimination of individuals of Indian origin in South Africa.

\subsection{The 1940s and 1950s: apartheid becomes an issue}

No publications in Iceland, documented on the website timarit.is, were found that discussed apartheid during the 1940s or earlier. The first news on racial oppression in South Africa is found in August 1946 in Djódviljinn (1946a), the newspaper of the SP, reporting that the Indian National Congress in South Africa had filed a complaint of racial discrimination at a peace conference in Paris. Icelandic representatives attended the General Assembly of the UN for the first time in November the same year (Morgunblaðið 1946d, November 20). The SP refused to nominate a member to the UN delegation, seemingly assuming that the delegation would vote in support of South Africa, in line with the US and UK, which did not materialise (Alpýðublaðið 1946a; Morgunblaðið 1946a; 1946b; Djóðviljinn 1946b; 1946c).

When the Icelandic representatives returned home from the UN meeting, interviews with them were published in their respective party newspapers. The member of the IP reported that the disagreement between India and South Africa had been one of the most debated issues at the UN, and that the Icelandic vote had become the deciding one in favour of India (Morgunblaðið 1946c). The member of the PP however underlined the fact that Iceland did not line up with any of the superpowers in the voting (Tíminn 1946), and the member of the SDP recounted that the leader of the Indian delegation had expressed a particular appreciation of the Icelandic voting (Alpýðublaðið 1946b). Not only in 1946, but also in 1947 and the early 1950s, did Iceland occasionally vote for a firmer stance against apartheid at the UN than most other European countries did, and the authority of the UN in addressing apartheid was never questioned (Valdimarsson 1993, 195-204). 
Searching for apartheid on timarit.is resulted in ten hits in Icelandic newspapers and magazines in the 1950s, and there are five articles in which opinions on the topic are expressed. The first one is an article published in 1952 in the weekly magazine Fálkinn (1952), which critically outlines the apartheid policy. Another article, published in the newspaper of the SDP, rejects the apartheid policy and compares it with the Nazi politics of Hitler (Alpýðublaðið 1953). Apartheid is also condemned in Kirkjuritið, published by The Evangelical Lutheran Church of Iceland (Árnason 1956), and in a journal published by the University Student Association (Stúdentablaðið 1957). In contrast, Lesbók Morgunblaðsins $(1957,169)$, the newspaper of the IP, argues that the recent discussion of hatred and persecution against black people in South Africa within the UN and elsewhere is "a communist propaganda aimed at destroying the collaboration of Western states.”

\subsection{The 1960s and 1970s: increased awareness}

The number of results identified by searching timarit.is for apartheid increased in the 1960s and 1970s compared to earlier decades. It peaks during the Sharpeville shootings in 1960, Mandela's sentence of life imprisonment in 1964, and the Soweto uprising in 1976. Some of these publications accepted the standpoint of the South African regime, using the communist stamp as an argument against the ANC, while others rejected it. Nonetheless, arguments in support of apartheid based on outspoken racism and bioevolutionary arguments are rare.

In 1961 and 1962, Iceland and the other Nordic countries abstained from voting on a resolution in support of sanctions (Valdimarsson 1993, 196; 199). Again in 1965, Iceland abstained from voting when the UN General Assembly supported Resolution 2054 A (XX), which argued for sanctions against South Africa. Finland and Norway also abstained from voting, but Sweden and Denmark voted for the resolution (Sellström 2002, 394). In 1966, all five Nordic countries voted for a resolution on an arms embargo and, for the first time, they condemned apartheid as a crime against humanity. The majority of Western countries opposed the resolution and a similar one in 1968, which was again supported by all the Nordic countries (Valdimarsson 1993, 199-200).

During the 1970s, the Nordic countries continued to vote for resolutions on an arms embargo but began also voting for economic sanctions, opposed by most other Western countries (Valdimarsson 1993, 200-204). In 1970, 1971 and 1972, Iceland voted for resolutions at the UN in support of economic sanctions and declared that armed struggle was a rightful means to fight apartheid, while the other Nordic countries and most Western countries abstained from voting or opposed these resolutions (Valdimarsson 1993, 204-207). It is noteworthy that in 1970 Iceland had a centre-right government. In the following year, a new left government unilaterally expanded the fishery limits from 12 to 50 miles, and a new Cod War with the UK broke out. The former centre-right government had already initiated preparations for the expansion of the fishing limits in 1967, and in 1969 Iceland's speech at the UN underlined support for Third World countries and the importance of protecting natural resources. 
In 1976, 1978, 1979 and 1980, the Nordic countries continued to vote for resolutions against apartheid that most other Western countries objected to or abstained from voting, but these were not as radical as those Iceland voted for in 1970, 1971 and 1972 (Valdimarsson 1993, 202-203). The Nordic countries worked on a draft resolution for the UN that resulted in a Nordic Programme of Action against Apartheid - also referred to as the Oslo plan - agreed upon in 1978 by all the Nordic foreign ministers (Sellström 2002, 492-493). The programme, which included the 'prohibition or discouragement of new investments', the disruption of events within sports and culture, and provision of aid to the liberation movements in Southern Africa was executed differently in each of the Nordic countries.

The first documented anti-apartheid activities carried out within Iceland appeared in the late 1960s and early 1970s. Several newspapers reported on the human rights week organised by the Youth Association of Iceland in 1965. It focused on the human rights violations in South Africa, and honoured the five-year anniversary of the Sharpeville massacre. According to interviews with former activists (Nordic Africa Institute 2009), apartheid demonstrations were spontaneous actions, i.e. they were side events during demonstrations on the annual Labour Day or at the NATO meeting held in Reykjavík in June 1968. These manifestations did however not receive media attention.

During the 1970s, there was an array of leftist organisations in Iceland that published articles in their journals on the liberation struggles of the Portuguese colonies and other colonies in Southern Africa (Nordic Africa Institute 2009). The trade unions were also active. They had good relations with their sister organisations in the other Nordic countries, which offered encouragement, information and material on apartheid in the form of booklets, pamphlets and posters. The Evangelical Lutheran Church of Iceland was a member of the International Council of Churches, which held a critical stance towards apartheid. However, the Church did not organise any anti-apartheid events that attracted the attention of the newspapers, although church members occasionally wrote articles that condemned apartheid (Nielsson 1963; Jónsson 1976; Árnason 1956). In 1978, the leaders of all political parties with representation in Parliament, the Bishop of the Evangelical Lutheran Church, and others signed a declaration advocated by Amnesty International that condemned apartheid as a crime against humanity (Tíminn 1978).

\subsection{The 1980s: decade of action}

During the 1980s, there was an explosion of publications on apartheid. Most commentators who were against sanctions typically took care to condemn apartheid as an ideology before forwarding messages in favour of the white minority in South Africa (Eyjólfsson 1988). It was argued that sanctions would increase the suffering of the black population, and that human rights violations were common elsewhere in the world (Stephensen 1988). Outright racist views were occasionally expressed: the Icelandic consul in South Africa was for instance outspoken about his views of 'the niggers' (Dagblaðið Vísir 1985).

The 1980s was the decade of concrete actions carried out against apartheid. In the 
early and mid-1980s, events were organised to raise public awareness about the situation in South Africa and persuade Parliament to adopt economic sanctions. The Apprentices Union, with their leader, Kristinn Einarsson, was active in arranging such events. In 1983, the union joined the Nordic Operation Day's Work, with the objective of educating youth about apartheid and raising funds through one day of work. Considering the representation of the ANC in the Icelandic mass media as communists and a terrorist organisation, in 1985 the union decided to support educational efforts organised by the South African Council of Churches (Sigurgeirsson 1985; Morgunblaðið 1985). However, at the last minute, the minister of education did not endorse a day off from school for students (Djóðviljinn 1985a).

In 1984, Iceland was among 22 countries that drafted a UN resolution to eradicate apartheid, adopted in the General Assembly by all countries except the US and the UK while six countries abstained (Reddy 2008, 78). By adopting the resolution, referred to as Resolution 39/72 G, the countries declared their commitment to adopt sanctions against the South African regime. Furthermore, in 1985, Iceland participated in a renovation of the Nordic Programme of Action against Apartheid, agreed by the Nordic countries in 1978 (Sellström 2002, 493). Nonetheless, uncertainty about the adoption of sanctions prevailed in Iceland.

In August 1985, the activists Sigurlaug Gunnlaugsdóttir and Gylfi Páll Hersir interviewed Neo Numzana, head of ANC's delegation at the UN in New York. Although none of the Icelandic newspapers was willing to publish the interview, the meeting resulted in the establishment of formal contact with the ANC in Copenhagen. In October 1985, Aaron Mnisi, the ANC representative in Copenhagen, visited Iceland and met with the trade unions, political parties and youth organisations. Inspired by his visit, the dockworkers' labour union, Dagsbrún, adopted a ban on unloading South African goods (Hersir \& Sigursveinsson 2006; ÁB 1985). Although the ban was later ruled illegal, it received much media attention, and the demands for sanctions against South Africa became stronger. As noted earlier, the Icelandic Church was a more outspoken critic of apartheid abroad than domestically. In a meeting in September 1985, all the Nordic bishops urged their governments to adopt sanctions against South Africa (Pjóðviljinn 1985b).

The spring 1988 was pivotal for the anti-apartheid struggle in Iceland. On 24 March 1988, all the Nordic ministers of foreign affairs once again agreed on a 'Nordic Action against Apartheid' (Eriksen 2000). At that time, Iceland had not yet adopted any sanctions and questioned the effect of such actions "since most of the economic activities against South Africa (outlined in the Programme of Action) are not relevant to Iceland and because there is minimal trade between Iceland and South Africa" (Sellström 1989, 37). Early spring 1988, Fritz Dullay, an ANC representative in Copenhagen, visited Iceland. He met with the Minster of Foreign Affairs and other politicians, addressed meetings and as a screening of the film Cry Freedom (Morgunblaðið 1988). On 10 May 1988, the Icelandic Parliament adopted Act No. 67/1988, which argued for a trade embargo of products from South Africa and Namibia. All members supported it except two from 
the right wing Citizen's Party who argued that sanctions were ineffective and human rights violations were not only a South African problem (Magnússon 1988).

Following legislation of the trade embargo, on 28 May 1988 engaged individuals and groups founded SAGA, a unified anti-apartheid association (Pjóðviljinn 1988). Among the founding members were trade unions, the SDP, the PA, the Association of Icelandic Students Abroad and Women for Peace and Culture, as well as approximately 200 individuals. There was however no religious organisation among the founding members, and the Students' Council of the University of Iceland rejected a proposal to become a member based on the argument that it was beyond the Council's function to engage in politics, and under no circumstances could it support 'terrorist groups' like the ANC (Gunnlaugsdóttir 2009).

\section{SAGA in action}

Considering the small size of the Icelandic population, SAGA was a large organisation from the beginning, with hundreds of members. Nonetheless, only a few were active in the long run. Who were these individuals, why did they become engaged and what did they do? In what follows, the activists tell their story.

\subsection{Who were the activists?}

Those who became active members of SAGA can be divided into two main groups. Firstly it was a group of activists who had been taking part in anti-apartheid activities since the late 1960s, and secondly, the young recruits who joined SAGA in 1988, or later.

Some of the activists had become politically active in the late 1960s and 1970s, and their engagement was captured by the political spirit of the time. An activist explained that the year 1968 was central given the Vietnam War, apartheid and Chile: "Being an activist, made me think not only about my being in Iceland but like a member of bigger community - I had to be responsible". Another activist mentioned the Vietnam War, decolonisation and the struggles of Third World countries as a background to his political engagement. Some began to take part in anti-apartheid activities, inspired by human rights and moral issues. They were fighting "unfairness" and for them "it was easy to get engaged" and important to be "morally responsible." According to one, "I just thought that apartheid was a totally despicable, disgusting system, and that was what motivated me. Some of the things were just unbelievable, so I wanted to do my little bit."

The activists did not refer to a personal experience as a source for their activism, e.g. by knowing somebody who had experienced apartheid or having visited or lived in South Africa or another Third World country. In fact, none of the activists had visited Africa when they joined the anti-apartheid movement, and only a few of them subsequently visited Africa. However, some of them had lived abroad, where they had joined anti-apartheid movements. One was active in such a group when studying in Denmark during the late 1970s and early 1980s. Another had stayed in several countries and he had taken an active role in the establishment of an anti-apartheid movement in Norway 


\section{STJÓRNSÝSLA}

in the 1970s. Still another of the older generation had joined a German movement for some years that was engaged in anti-apartheid activities. Some of the young activists had also lived abroad where they became involved in anti-apartheid movements. For instance, two young female SAGA members had stayed in London for some time, where they joined The City of London Apartheid Group. Upon joining SAGA, they brought a particular tradition of demonstrations and advocacy, including the singing of South African songs.

\subsection{The first challenge}

The first major event organised by SAGA was a concert to celebrate Mandela's 70th birthday on 17 July 1988. Its slogan was Free Nelson Mandela 70 years. It was a success, attracting significant media attention. The most popular Icelandic music groups participated, or as one of the main organisers explained it "there was an Icelandic pop group that was pretty much world famous - The Sugar Cubes - and their lead singer was Björk. They were the first group that we asked if they were willing to perform, and that was an easy yes." Despite huge attendance, the event left SAGA in debt. The concert took place outdoors, and many did not pay the entrance fee but still enjoyed the music from the side of the arena, as one activist explained. According to the news, the artists performed without getting paid, and the profits were to be in support of children and youth tortured in South African prisons (Dagblaðið Vísir 1988). Nevertheless, there were no profits. The concert was broadcast on TV and radio, however, during the break, when the ANC representative in Copenhagen, Aaron Mnisi, addressed the public, the TV transmission was halted.

Some of the activists who had invested weeks of work to prepare for the concert were exhausted. There were also conflicts within SAGA, which had an open democratic structure with neither a board nor a chairman. Those who attended meetings made the decisions. After the concert, it was decided that there would be a chairperson, a board and a new constitution. Kristinn Einarsson, the former leader of the Apprentices Union, became SAGA's first elected chairperson. Later, he had to move to the east coast of Iceland for a new job. A few members withdrew from SAGA, and others moved abroad. Simultaneously, a group of young high-school students entered the organisation, and a new generation took over. The leadership of the group was mainly taken over by young girls, and securing the implementation of the embargo was seen as urgent.

\subsection{Mastering the message}

Implementation of the embargo on South African goods was SAGA's main objective, in addition to raising awareness among the Icelandic population about the inhumanity of the apartheid system. The approaches used were manifold: the writing of articles in newspapers; arranging meetings, demonstrations and concerts; producing educational materials, visiting schools, singing and distributing information on the streets or at organised events. Fundraising was also an important task. Activists sold literature and earned money from singing, and SAGA received membership fees and some donations. 
Registered members who ceased to pay were contacted and urged to continue with their financial support.

The activists spent most of their time appealing to consumers not to buy South African products. Every week they went to downtown Reykjavík to sell badges, distribute leaflets, and tell people about what was going on in South Africa. They regularly stood outside grocery stores to bring consumers' attention to South African goods. The activists had pamphlets and materials in the Nordic languages and in English, which one of them had obtained through contacts from former engagements in the antiapartheid movement in London. They distributed lists of South African companies whose products were for sale and encouraged people to avoid them. They also showed videos or documentaries with horrific photographs of the situation in South Africa. Not everyone liked them and some passers-by complained. "I remember when we stood outside the stores, the majority of the people found it rather irritating, but there was always someone who stopped and actually asked us for more information," an activist recalled. The SAGA choir had some 15-20 members, often singing downtown, in front of grocery stores or at particular events, with a licence they obtained from the police. Singing was seen as a good way to attract attention, and a new approach for political activists in Iceland.

The activists also entered the shops and took positions at the side of the canned fruits and informed the customers about products manufactured in South Africa. Identifying South African products was not always that easy as the importers had at times relabelled canned fruits from South Africa such that they appeared to be from the Netherlands. Thus, when they ripped off the 'Made in the Netherlands' label, another label 'Made in South Africa' was visible. The activists had stickers they had received from London, and they put these on the South African products. The activists were not popular among the cashiers, as one of them explained, in particular when they took direct action in the form of filling a trolley with South African goods, emptied the contents onto the conveyer belt and left it there. At times, the shop owners would call the police. Some activists were arrested or had to remain at the police station for a while. They preferred to be detained, especially if the event would get on the news. The worst outcome was no media attention. One activist recalled how the police had asked them to get into the police car. Then they drove near to the police station and asked the activists where they wanted to get out of the car. The policeman explained they had only offered the activists a lift, something that disappointed the activists who wanted detention.

Some actions were considered more successful than others. A particular successful event occurred when some activists demonstrated against tourism in South Africa at Keflavík International Airport. According to one of them, the advertisement from the travel agency was quite offensive, as it hinted that apartheid would not be visible to the holidaymaker. The activists tried to prevent travellers from entering the airport, but they were unsuccessful because they did not want to use violence. In fact, the travellers "got quite angry with us," one explained. Nonetheless, the activists were happy - their actions were highlighted in the media. Receiving media attention was seen as crucial, and writing 


\section{STJÓRNSÝSLA}

articles was a conscious strategy. There was a great difference in the press with regard to the acceptance of articles. Pjóðviljinn, the newspaper of the PA, frequently published articles on apartheid. In contrast, the newspaper for the IP, Morgunblaðið, was regarded as difficult. An activist argued that it "was basically telling a side of the story that was more acceptable to the apartheid government". Still, Morgunblaðið published some of their articles, albeit reluctantly.

\subsection{Being part of a bigger movement}

The ANC's network in the Nordic countries, Western Europe and the UK was crucial for the work of the activists. They were in contact with the ANC and organised speaking tours for their representatives. Such visits were seen as crucial to enforce the work and the spirit of the activists but also to attract media attention and for recruitment of new members. Trade unions often financially supported such visits, and occasionally the Ministry of Education gave grants. Lecture rooms and accommodation were frequently offered free of charge. The SAGA activists celebrated for instance Mandela's release from jail and on 1 March 1990 with a concert. Fritz Dullay, the ANC representative gave an address at the celebration and met with the prime minister and the minister of foreign affairs, in addition to activists and other organisations (Djódviljinn 1990a). The activists lamented however that Mandela did not visit Iceland during his tour to Europe later the same year. The Foreign Ministry did not want to organise such a visit.

The SAGA activists were enthusiastic about Mandela's release from jail and the following dismantling of apartheid. "I think, being a leftist-activist, I have not often had the feeling of being part of the winning team," one argued. Knowing that Mandela was released from prison was great: "I felt so happy and proud ... even though I did not do so much to change this. However, maybe I did help a little bit." The activists were humble when considering their own contribution to the success. One argued: "Maybe we did not do much, but when everyone is doing something, it counts." Another found it selfish to claim a role in the success; however, he hoped that his role had some tiny importance. He noted that SAGA was simply "a part of the global stream that washed the apartheid away". The activists underlined that in the total context, their efforts were a small contribution. Still, they were part of a bigger movement.

One activist argued that it must have been encouraging for those who suffered from apartheid to know about all the people who supported them, "but, I can't say that they knew about this little group in Iceland. Not to diminish it in any way, but we were young, and we were not extremely organised." Others argued that their work affected the opinions of their compatriots. One said: "well, I am sure that we woke some people up. That is the main thing that we were able to do, to get people to say no." Another maintained, "what happened here was more a sort of raising the level of awareness of the Icelandic people." Still, one believed that "in the end, most people supported the struggle of the majority in South Africa."

After Mandela's release from prison, the activists continued to write articles and 
work against trading with South Africa. They also organised a series of seminars on South Africa, and the contact with the ANC continued. However, the group had begun to scatter in 1992, and the intensity of their work gradually declined. In the winter of 1993, SAGA members were asked to meet with the Parliamentary Commission of Foreign Affairs to hear their opinions on lifting the embargo on South African goods. They forwarded the position of the ANC not to lift the ban until free elections had been implemented in South Africa in line with the ANC statement on the ban. Nevertheless, Parliament withdrew the ban on 27 April 1993.

The last event the SAGA activists organised was a memorial seminar to honour Mandela held at the Nordic House in Reykjavík on 18 December 2013 (Efling n.d.). At his death, the members of Parliament honoured Mandela as well (ruv.is 2013).

\section{Discussion}

This article explores Iceland's involvement in the global anti-apartheid struggle of the $20^{\text {th }}$ century. In the late 1940s and early 1950s and again in the early 1970s, Iceland voted on more radical UN resolutions on apartheid than did other neighbouring countries (Valdimarsson 1993). In contrast, Iceland was later to adopt a ban on imports of South African products and to establish a unified anti-apartheid movement than its neighbouring countries. Nonetheless, the activists, incorporated into the transnational anti-apartheid network, invested much of their time aiming to eliminate apartheid and liberate South Africa.

The setting for this exploration of anti-apartheid struggle is Iceland. In line with Walder (2009) and Thörn (2006b), the history, economic interests and political culture shed some light on Iceland's outlier voting compared to neighbours and the inconsistency in acting abroad and at home. Likewise were the motives and challenges of SAGA's activists influenced by these factors.

\subsection{Iceland's ambiguous involvement}

There is a notable difference between Iceland's voting at UN anti-apartheid resolutions and the neighbouring countries, and there is also a discrepancy between international commitments compared with the domestic one.

The early Icelandic voting in the UN occurred during a period when the Icelandic centre-right government was negotiating membership of NATO, agreement on US military bases, and assistance under the Marshall Plan. Despite being the biggest recipient per capita of Marshall Aid, Iceland did not vote in line with the interest of the US, indicating considerable bargaining power. Valdimarsson (1993, 204-207) suggests that due to its recent independence Iceland's UN voting against apartheid during its first years as member of the UN can be explained with solidarity. The national political culture may also have influenced the position taken (see Jónsson 2014; Thorhallsson 2013). The SP seemingly assumed that the Icelandic UN delegation would lean towards the position of the US and the UK, which was not the case. When back home, the 


\section{STJÓRNSÝSLA}

emphasis of the Icelandic representatives on the objectivity of their vote is likely to have been in a response to the hotly debated issue (Morgunblaðið 1946c; Tíminn 1946; Alpýðublaðið 1946b).

After the disappearance of herring in 1967, and a decline in the cod catch, Iceland went through a period of economic crisis in the late 1960s and early 1970s (Ingimundarson 2003). With foreign fishing vessels that accounted for half of all catches, securing an extension of the fishing zone was regarded as a priority, and Iceland used its strategic geographical military position to further its interests within NATO. In addition, as Valdimarsson (1993, 204-207) argues, Iceland exploited their voting on apartheid in the UN to get support from Third World countries for the extension of fishing limits. Thereby, the former normative foreign policy towards apartheid shifted towards realism, which coincides with Thorhallsson's conclusion that "the Icelandic political elite has had a realist conception of foreign policy" and used to put economic interests in the foreground $(2013,13)$.

Despite being supportive of sanctions against the South African regime abroad, the representatives of the Icelandic state resisted for a while similar actions at home. Economic interests can hardly explain the late adoption of the Icelandic Parliament of an embargo two years after the US Congress had adopted the Comprehensive AntiApartheid Act. The centre-right government had already supported the UN and Nordic Council agreements that urged countries to adopt sanctions against South Africa. Simultaneously sanctions were regarded as useless due to limited economic transactions between Iceland and South Africa. The confrontational political culture and consequent hostile relations between the centre-right political establishment on one hand and trade unions, leftist politicians and activists on the other hand (see Jónsson 2014) are may have contributed to the reluctance to adopt the embargo. Why then was the embargo finally adopted? 'The most reasonable answer appears to be in line with norm-based theories, arguing that "states may make changes in their behaviour" because they are concerned about their image both domestically and abroad (Sikkinik 1998, 520). All their neighbours had already adopted sanctions at the time.

\subsection{Cold War politics and SAGA's establishment}

Thörn (2006b, 286), concerned with how the transnational anti-apartheid movement emerged in times of a new global political culture, argues that the movement "was able to unite an extremely broad 'rainbow coalition' of organizations and groups, with extremely diverse social bases and ideological orientation.” Yet, Cold War politics was a challenge; ANC's links with the South African Communist Party and the Soviet Unions was delicate issue for the activists, not least the South African ones (Thörn, 2009). ${ }^{2}$

In Iceland, as elsewhere, the Cold War discourses tainted the image of the ANC portraying them as a communist threat and terrorist organisation to such a degree that many ignored the severe breaches of human rights in South Africa. Consequently, most of those who were engaged in the anti-apartheid activities belonged to the left or the labour unions. The late establishment of SAGA, in comparison of the neighbouring 
countries is notable. That might have relation to the fact that, according to Thorhallsson (2013, 11), "a new bilateral defence agreement with the US signed in 1951 and the presence of a US military base, were extremely controversial and overshadowed other political issues in the country during the Cold War." Leftist activists of that time were busy protesting against the US military base and Iceland's membership in NATO.

Finally, a group of activists who had already taken part in leftist political action and protests in the 1960s and 1970s eventually worked for the establishment of SAGA in 1988. As evident from the interviews with former activists, until late 1980s, forwarding of anti-apartheid messages was a side event to other demonstrations. Notably, the 'rainbow coalition' of organizations that joined SAGA at its establishment was limited, neither the Evangelical Lutheran Church of Iceland nor the University Student Association in Iceland became members of SAGA. Yet, in the 1980s the bishop took an active position against apartheid in a Nordic context and at home, and some of the Church's representatives were outspoken about their critique against apartheid since the 1950s. Despite being step-sided by such an important allies as the Church and the University Student Association, at first SAGA had many members and member organisations but only a small group of activists came to take part on the anti-apartheid activities on regular basis.

\subsection{Political and emotional engagement}

Within short, the predominantly young, female SAGA activists took over the organisation. Some had come into contact with anti-apartheid movements abroad, which influenced the activities organised in Iceland.

SAGA's main role was to enforce the implementation of sanctions against the South African regime, which included make the population aware of the cruelty of the apartheid. The activists spent much of their time informing about apartheid and preventing their countrymen from buying South African products, mostly canned fruits. As elsewhere, the transnational networks of anti-apartheid movements played a crucial role in supporting the work with written material, strategies and encouragement (Thörn 2006a), and the use of mass media for distribution of information was at the centre of the work (Thörn 2007). The activists struggled to further their views in television, journals and newspapers, as well as at public appearances and through private faceto-face communication. Their messages were forwarded through badges, pamphlets, booklets, pictures, films, personal communication and songs and the aim was to provoke feelings of indignation, sympathy and joy (see Jasper 2011).

While generally holding leftist political views, the activities tended to define the antiapartheid struggle as a human rights issue rather than a political one. Their focus was on the moral wrongs and inherent injustice of the apartheid system. What motivated the SAGA activists was, as formulated by Jasper $(2011,14.7)$, "[t] he desire to have an effect on the world." The ultimate goal to abolish apartheid was at the same time based on rational argument for equal rights for all human beings and an emotional and moral call for justice. The power of music was evident: singing was a satisfactory collective 


\section{STJÓRNSÝSLA}

action that helped activists approach new audiences. The activists spent much of their time trying "to nudge a person from bystander to participant" (Jasper 2011, 14.8), and as formulated by Jasper $(2011,14.13)$, "[ $\mathrm{t}]$ he pleasures of conversation, the excitement of interaction, the ability to articulate moral intuitions, a sense of making history, and others: these are satisfactions that keep participants going."

The Icelandic anti-apartheid activists' engagement, their activities and personal experience resemble somewhat with that of other activists. As elsewhere the visits by the ANC exiles, who travelled between the locally based anti-apartheid movements, were central for mobilisation through interviews in the media, addressing public events, and meeting with politicians. Such visits were also a boost for "the individual's motivation to engage in, as well as to sustain, solidarity action through the years" (Thörn 2010, 18). These visits created transnational solidarity and reinforced the focus on the ultimate goal to free South Africa from apartheid. Rather than prior personal experience, motivation to take action was rooted in political conviction and a moral cause. They wanted to change the world, and their goal to abolish apartheid and liberate South Africa was based on a political argument for equal rights for all humans and an emotional call for justice.

\section{Conclusions}

This article aims to compensate for Sellström's dismissal of Iceland as relevant for research on the Nordic countries contribution to the liberation of Southern Africa. It describes Iceland's involvement in the global anti-apartheid struggles with focus on UN voting, adoptions of sanctions against the South African regime and establishment of a unified anti-apartheid movement in Iceland its organisation and activities. Then, it explores in some details the anti-apartheid activists; their actions, motivations and personal engagement.

Scholars agree that international struggle against apartheid was challenged by cold war politics and economic interests while the emphasis on decolonisation and human rights contributed to disapproval of the racial discrimination in South Africa (e.g. Skinner 2009; Sapire 2009; Thörn 2006a, 2009, 2010). In two periods of time, Iceland voted for more radical anti-apartheid resolutions at the UN than their neighbours. The former case may be explained with solidarity as a newly independent country. In voting on resolutions at the UN in the early 1970s, Iceland supported likely allies for an extension of the fishing limits, i.e. Third World countries, independent of the political ideology of the Icelandic governments at that time. The confrontational political culture, described by Jónsson (2014), is more likely to have contributed to the resistance to adopt a national embargo against South African products in the 1980s rather than economic interests, which were minimal. Likewise, the political culture, reflected in the fierce branding of the $\mathrm{ANC}$ as a communist organisation, is likely to have resulted in the largely leftist political orientation of the anti-apartheid activists, and the relative absence of religious groups and university students.

Considering Iceland's colonial history, an economic dependence on a single resource, 


\section{STJÓRNSÝSLA}

and a rough political culture, the local context in Iceland may have differed somewhat from that of the neighbouring countries. Otherwise, the anti-apartheid struggle was influenced by the same global trends, including cold war politics, condemnation of colonialism and emphasis on human rights, as the other neighbouring countries. As elsewhere, embedded in the transnational anti-apartheid network with particular ways of organisation and mobilisation (Thörn 2006a), the overwhelmingly young SAGA activists were concerned with politics, human rights and solidarity, and in terms of dedication and effort, their involvement was in no way marginal.

\section{Notes}

1 The author is grateful to Sigurlaug Gunnlaugsdóttir, Dórdís Sigurðardóttir and Geir Gunnlaugsson for comments on a draft of the article. Thanks to the Nordic Africa Institute in Uppsala and Proscovia Svärd for adding Iceland to the Nordic Documentation on the Liberation Struggle in Southern Africa Project, and for the data published on its website.

2 According to Thörn (2010), the influence of the Cold War on the anti-apartheid struggle is under researched.

\section{References}

Alpýðublaðið. (1946a). “Hvað segja hin blöðin?”, 14 November. - (1946b). "Finnur Jónsson dómsmálaráðherra segir: Heimurinn á alla framtíð sína undir starfi Sameinuðu pjóðanna”, 19 December.

- (1953). "Kynpáttaofsóknir í nafni guðs", 17 May.

ÁB (1985). “Leiðari: Viðskiptabann á Suður-Afríku”, Djóðviljinn, 50(240), 4.

Árnason, G. (1956). Pistlar: svartur blettur. Kirkjuritid 22(2), 62-64.

Dagblaðið Vísir (1985). “Íslenskar krónur kaupa kúlur harðstjóranna í Suður-Afríku - segir sendimaður Afríska pjóðarráðsins um ávaxtakaup Íslendinga frá S-Afríku”, 18 October.

- (1988). "Frelsum Mandela sjötugan", 15 July.

Efling (2013). "Minningar og virðingarsamkoma Nelson Mandela”, http://www.efling.is/minningarog-virdingarsamkoma-nelson-mandela/

Einarsdóttir, J. (2009). Seminar Report: The Nordic Documentation Project on the Liberation Struggles in Southern Africa: The Icelandic People's Involvement and Lessons Learnt. Reykjavík: Nordic Africa Institute, Uppsala.

Eriksen, T.L. (ed.) (2000). Norway and National Liberation in Southern Africa. Uppsala: Nordic Africa Institute.

Evenett, S. J. (2002). "The Impact of Economic Sanctions on South African Exports", Scottish Journal of Political Economy 49(5), 557-573.

Eyjólfsson, G. (1988). “Kjallarinn: Mandela og minnihlutinn”, Dagbladið Visir 78/14, 164, 14.

Fálkinn. (1952). "Kynkvíslaofsóknir í Suður-Afríku”, 26 September.

Goodwin, J. and Jasper, J. M. (2006). "Emotions and social movements", in J. E. Stets and J. H. Turner (eds.), Handbook of the Sociology of Emotions. New York: Springer US.

Gunnarsson, G. Á. (1996). "Ísland og Marshalláætlunin 1948-1953”, Saga, 24, 88-128.

Gunnlaugsdóttir, S. (2009). “'Students’ er ekki alltaf 'stúdentar”, 16 March, mbl.is, http://www.mbl.is/ greinasafn/grein/1274132/

Gurney, C. (2000). "A Great Cause: The Origins of the Anti-Apartheid Movement, June 1959-March 1960", Journal of Southern African Studies 26(1), 123-144.

Hersir, G. P. and Sigursveinsson, J. T. (2006). "Félagslegir ávinningar í kjölfar baráttu: Öld liðin frá stofnun Verkamannafélagsins Dagsbrúnar”, Fréttablað Eflingar-stéttarfélags 2(11), 26-31.

Indridason, I. H. (2005). "A Theory of Coalitions and Clientelism: Coalition Politics in Iceland, 19452000”, European Journal of Political Research 44 (3), 439-464. 


\section{STJÓRNSÝSLA}

Ingimundarson, V. (2003). "A Western Cold War: The Crisis in Iceland's Relations with Britain, the United States, and NATO, 1971-74", Diplomacy and Statecraft, 14(4), 94-136.

Jasper, J. M. (2011). "Emotions and Social Movements: Twenty Years of Theory and Research", Annual Review of Sociology 37, 285-303.

Jónsson, G. (2014). "Iceland and the Nordic Model of Consensus Democracy", Scandinavian Journal of History 39(4), 510-528.

Jónsson, J. (1976). "Kirkjan og Suður-Afríka”, Alpýdublađið 57(200), 6.

Kuziemko, I. and Werker, E. (2006). "How much is a seat on the Security Council worth? Foreign aid and bribery at the United Nations", Journal of Political Economy 114(5), 905-930.

Lesbók Morgunblaðsins (1957). "Ekki slæmt ástand", 17 March.

Magnússon, J. (1988). Umræður Efri deild: 95. fundur, 110. löggjafarping. 514. mál, bann gegn viðskiptum við Suður-Afríku og Namibíu. Alpingi, 9 May 1988.

Morgenstierne, C. M. (2003). Denmark and National Liberation in Southern Africa: a Flexible Response. Uppsala: Nordic Africa Institute.

Morgunblaðið. (1946a). "Hvers vegna kröfðust kommúnistar neitunarvalds?”, 7 December.

— (1946b). "Við einir skulum ráða!", 8 December. alsherjarpingi S.p.", 19 December.

— (1946d). "Sameinuðu pjóðirnar: Ræðu Thor Thors fagnað með dynjandi lófataki. Fullirúar Íslands tóku í gær sæti á pingi Sameinuðu pjóðanna”, 20 November.

(1957). "Ekki slæmt ástand", 17 March.

(1985). "Norræn samstaða um að vinna að menntunarmöguleikum svartra í S-Afríku á alpjóðaári æskunnar”, 20 March.

- (1988). "Fundur um málefni Suður-Afríku", 23 April.

Nielsson, Á. (1963). "'Páttur kirkjunnar: 'apartheid' og kristinn dómur”, Tíminn 47(180), 2/13.

Nordic Africa Institute. (n.d.) "Nordic Documentation on the Liberation Struggle in Southern Africa: Interviens - Iceland 2009", Uppsala, Sweden, http://www.liberationafrica.se/intervstories/interviews/ interviews-by-country/index.xml?node-id=1227322805-0

Reddy, E. S. (2008). The United Nations and the struggle for liberation in South Africa. In: South African Democracy Education Trust. The Road to Democracy in South Africa (volume 3), International Solidarity, part 1, chapter 2.

Roggeband, C. and Klandermans, B. (2010). "Introduction", in B. Klandermans and C. Roggeband, (eds.), Handbook of Social Movements across Disciplines. New York: Springer.

ruv.is. (2013). "Minning Mandela heiðruð á Alpingi”, 11 December, http://www.ruv.is/frett/minningmandela-heidrud-a-althingi.

Sapire, H. (2009). “Liberation Movements, Exile, and International Solidarity: An Introduction”, Journal of Southern African Studies 35(2), 271-286.

Sellström, T. (1989). "Some Factors behind Nordic Relations with Southern Africa", in B. Odén and H. Othman (eds.), Regional Cooperation in Southern Africa: A Post-Apartheid Perspective. Uppsala: The Scandinavian Institute of African Studies.

- (1999). Sweden and National Liberation in Southern Africa. Formation of a Popular Opinion 1950-1970 (Volume 1). Uppsala: Nordic Africa Institute.

- (2002). Sweden and National Liberation in Southern Africa: Solidarity and Assistance 1970-1994 (Volume 2). Uppsala: Nordic Africa Institute.

Sigurgeirsson, P. (1985). "Við förum inn og út úr fangelsi eins og pið farið í sturtu”, Morgunblađið 72(70), 26-27.

Sikkink, K. (1998). “Transnational Politics, International Relations Theory, and Human Rights”, Political Science and Politics 31(3), 516-523. 


\section{STJÓRNSÝSLA}

Skinner, R. (2009). “The Moral Foundations of British Anti-Apartheid Activism, 1946-1960", Journal of Southern African Studies 35(2), 399-416.

Soiri, I. and Peltola, P. (1999). Finland and national liberation in Southern Africa. Uppsala: Nordic Africa Institute.

Stephensen, Ó. D. (1988). "Viðskiptabann á Suður-Afríku: Skinhelgin skynseminni yfirsterkari”, mbl.is, http://www.mbl.is/greinasafn/grein/13851/

Stúdentablaðið. (1957). "Fréttir að utan: apartheid", 17 June.

Svärd, P. (2010). "The Nordic Documentation on the Liberation Struggles in Southern Africa Project", in C. Saunders (ed.), Documenting Liberation Struggles in Southern Africa. Uppsala: Nordic Africa Institute.

Thomas, G. (2011). "A typology for the case study in social science following a review of definition, discourse, and structure", Qualitative Inquiry 17(6), 511-521.

Thorhallsson, B. (2013). Iceland's Contested European Policy: The Footprint of the Past: A Small and Insular Society. University of Malta, Institute for European Studies.

Thörn, H. (2006a). Anti-Apartheid and the Emergence of a Global Civil Society. London: Palgrave Macmillan. (2006b). "Solidarity across Borders: The Transnational Anti-Apartheid Movement", Voluntas 17(4), 285-301.

- (2007). "Social Movements, the Media and the Emergence of a Global Public Sphere from Anti-Apartheid to Global Justice", Current Sociology 55(6), 896-918.

(2009). "The Meaning(s) of Solidarity: Narratives of Anti-Apartheid Activism." Journal of Southern African Studies 35(2), 417-436.

(2010). "Liberation Struggles in Southern Africa and the Emergence of a Global Civil Society", in C. Saunders, (ed.), Documenting Liberation Struggles in Southern Africa. Uppsala: Nordic Africa Institute.

Timarit.is. (2014). "Newspapers (Faroe Islands, Greenland, Iceland), European History Primary Sources (EHPS)", http://primary-sources.eui.eu/website/timaritis-newspapers-faroe-islands-greenland-iceland

Tíminn. (1946). "Ísland skipaði sér ekki í sveit með neinu stórveldanna á pingi sameinuðu pjóðanna: Ólafur Jóhannesson segir fréttir af störfum pingsins", 19 December.

— (1978). "Opið bréf til John Vorster: Stefnan yðar er glæpur gegn mannkyninu”, 19 March.

Valdimarsson, V.U. (1993). Ísland i eldlinu albjódamála: stefnumótun og samvinna innan Sameinuðu pjóðanna 1946-1980 [G.R. Árnason, and G.Á Gunnarsson (eds.)]. Reykjavík: Alpjóðamálastofnun Háskóla Íslands.

Walder, A.G. (2009). "Political sociology and social movements", Annual Review of Sociology 35, 393-412. pjóðviljinn. (1946a). Kynpáttakúgun í Suður-Afríku. 31 August.

(1946b). Ábyrgðin á framkomu Íslands í alpjóðamálum. 9 November.

(1946c). "Hneykslanleg afstaða íslenzku sendinefndarinnar á pingi Sameinuðu pjóðanna gagnvart Franco-Spáni”, 14 December.

— (1985a). "Ragnhildur gagnrýnd harðlega: Pingmenn skora á menntamálaráðherra að endurskoða afstöðu sína til að íslenskt œskufólk geti tekiðpátt í átaki gegn Apartheid-stefnu S-Afríku”, 28 March. - (1985b). "Apartheid: Biskupar krefjast aðgerða", 12 September.

(1988). "S-Afríku samtökin: Öflugur stofnfundur”, 31 May. (1990a). "Fulltrúi Afríska pjóðarráðsins á Íslandi”, 2 March. 
